\title{
The Importance of Class Actions for the Evolution of the Brazilian Collective Procedure
}

\author{
Luciano Picoli Gagno ${ }^{1,2}$, Thiago Felipe Vargas Simões ${ }^{1}$, João Bruno Costa Rodil ${ }^{2}$ \\ ${ }^{1}$ Vitoria Law School, Vitoria, Brazil \\ ${ }^{2}$ Law School of the University Vila Velha, Vila Velha, Brazil
}

\section{Email address:}

luciano.gagno@uvv.br (L. P. Gagno), thiago.simoes@uvv.br (T. F. V. Simões), brunorodil@outlook.com (J. B. C. Rodil)

\section{To cite this article:}

Luciano Picoli Gagno, Thiago Felipe Vargas Simões, João Bruno Costa Rodil. The Importance of Class Actions for the Evolution of the Brazilian Collective Procedure. International Journal of Law and Society. Vol. 3, No. 2, 2020, pp. 60-67. doi: 10.11648/j.ijls.20200302.13

Received: January 16, 2020; Accepted: February 13, 2020; Published: May 28, 2020

\begin{abstract}
In the present article, was investigated the contribution that the american experience with the class actions could offer to the Brazilian Collective Procedure and the idea of collectivization of individual lawsuits. Based on this proposal, were analyzed institutes of the Rule 23 related to the class action prerequisites, the types of class actions and the certification order, which is the judicial decision by which a claim is received as a collective in the US system. All these institutes were analyzed in a comparative and interactive way in relation to the institutes of the Brazilian system, in order to seek an improvement of the model of collective conflicts resolution existing in Brazil. It was used the deductive method, starting from general norms applicable on cases involving collective rigths, seeking the conclusion more compatible with our constitutional system, and the research was based in a bibliographical and jurisprudential exploratory technic, that allowed to know the different positions about the theme. At the end, we concluded that the American experience with class actions can contribute to the Brazilian practice linked to collective procedure and collectivization of individual demands, both when disciplining the prerequisites for the admission of a collective claim, and when define the hypotheses that could be subject to collective demands (types of class action) or the points that could be faced by the decision certifying a collective claim (Certification order).
\end{abstract}

Keywords: Collective Procedure, Prerequisites, Types of Class Actions, Certification Order

\section{Introduction}

This article focuses on addressing the following issue: how the US experience with collective actions (class actions) can contribute to Brazilian practice, providing our collective process with greater effectiveness and interaction with the individual model?

This question is justified by the growing importance that the collective process has been gaining in the global legal scenario, due to the new social formats and the mass legal relations typical of the modern world, composed of multiple individuals or based on a similar origin, which allows a uniform treatment by the Judiciary in order to obtain more isonomy and speed [1].

Moreover, the United States of America is the nation that presents if not the largest, one of the greatest levels of development in the use of collective process, called class actions, not only for the time of experience they have in this segment, as well as by the intensity of claims filed and judged in this format, producing effective results, with significant social transformations linked to civil rights, consumer rights and damages [2].

Thus, this research sought an analysis of fundamental institutes of North American class actions, such as: the requirements of admissibility of collective demands (prerequisites), the species of collective rights protected (types of class actions) and the requirements of the decision that accepts the demand as collective (certification order), because it is understood that they are determinant for the effective functioning of the alien system, can therefore contribute to a home system.

Regarding the admissibility requirements of class actions, the American experience can contribute to the Brazilian, when it lists important requirements that are practically ignored by our experience, such as, for example, the numerosity of class members, being certain still, that the application of adequacy of representation in the daily routine of collective demands is based on foreign experience [3]. 
When analyzing the types of class actions provided for Rule 23 (norm regulating the class actions procedure at federal level), it was highlighted important difference in the content of the US and Brazilian normative text, as well as the relevance that the identification of the type of collective right has to the legitimacy of the decision admitting a collective claim.

Finally, there was talk of the certification order, which is the decision that admits a lawsuit as a collective, fundamental point for our research, since in this decision should be faced some points, for example: the numerosity of the classes members, the adequacy of representation of the author, the kind of collective right at issue, the class replaced, its claims and its foundations, points that may receive different nuances in our system, but which will be fundamental to the quality of the jurisdictional activity to be performed and for substantial litigant participation.

\section{The Relevance of the American System of Class Actions to the Idea of Collectivization}

The United States of America is the country with the most advanced level in the use of collective process, disciplined by Rule 23 - Federal Rules of Civil Procedure [4], which is due more to cultural factors than just legislative conditions.

In legislative terms, that is of sufficiency of the existing rules to provide good practical results, it must think that Brazil does not owe to the US legislation, quite the contrary, the technique foreseen in Brazil has several different solutions than those presented in the American rule and that, at least for our reality, must be translated into more appropriate and convenient results.

Nevertheless, in practical terms, the American class actions are light years ahead of the Brazilian collective actions, either because they are much more used, or because its use has already presented and presents effectively transformers results of the social reality, which can be verified based on examples such as: the Brown $v$ Board of Education case [5] by means of which was combated the racial segregation in American schools; the case of structural reform aimed at improving the conditions of the public hospitals for treatment of people with mental problems [6] or; cases involving collective damages by the use of orange agent, asbestos or breast implants [7], through which thousands of victims were compensated.

In Brazil, due to cultural issues, typical of the legal culture related to civil law, it still do not have such expressive practical results in the field of collective protection, being the most important results linked to actions for impropriety and violations of consumer or social rights.

Moreover, it is also true that the delay in obtaining a decision on the merits of collective actions is another factor of damage to the expected results, which is also very different from the American reality, where many collective claims are subject to setlements shortly after their certification by the Court [8] and, even when there is no agreement, the procedural delay does not appear to be as serious problem as it is for us.

Nevertheless, it can be said that the study of US legislation on class actions is important for the better understanding and use of the collective process around the world, whether by the practical importance of the use of class actions redress in the USA, which, one way or another, is also result of the advance of existing legislation, or the by the longevity of such legislation, which already has almost a century of existence, counting with the reforms of the 20th century [9].

It is important to note that only strong legislation does not generate all the expected results in a cultural environment contrary to the propositions contained in such law, but it is less sufficient has only a cultural environment conducive to the development of a legal context without the existence of a norm governing such context; based on this premise, the importance of Rule 23 for the prominent role of the US in the global collective process scenario is assumed, despite this norm acting together with a cultural discernment much more conducive to such development.

In this context, the importance of an analysis and understanding of the North American system of class actions, disciplined by Rule 23, it is due to the fact of believe that, through this experience, we will be able to build good justifications for the study of the tendency of collectivization of individual demands and find good answers to the challenges that this technique would face.

Of this, because class actions are understood as an efficient model of collective rights protection, this topic was sought his study, for that imported precepts of that field contribute with, for example: the moment for the judge to analyze the admissibility of the conversion of an individual claim into a collective one, the way to discern and classify the collective action into concrete, and the way to decide on the collectivization or not.

The study of the prerequisites of class actions undeniably can contribute providing bases to assist in the judgment of admissibility that the Brazilian judge makes on collective actions (especially in the hypotheses in which he has to convert an individual action into a collective one), a discussion that in Brazil is summarized around the institution of procedural legitimacy, ignoring other very important ones such as numerosity of class members and the community of interests, for example.

Already the study of class actions types, helps a lot in understanding the types of collective actions that can be handled in Brazil, where there is also a dichotomy that between demands concerning indivisible rights and demands concerning homogeneous individual rights, despite the profound difference in the form of normative predictions from Brazil and USA.

Moreover, the understanding of the certification order or the decision that judges whether a claim can or not proceed as a collective can fatally provide useful knowledge to the improvement of the Brazilian judicial decision on the matter (especially when such decision is taken by converting 
individual action into collective action), point that is also not subject to more detailed studies in our system, due to the lower prominence that is given to certification here, which identifies with the exam of the initial petition.

In any case, the American prediction that the judge should define the class, its pleas and fundaments, and this can be changed at any time before the final decision, indicates the need for special attention with these points also in Brazilian practice, when making the preliminary decision or when converting individual demand into collective.

In the following topics then, some relevant aspects related to the use of collective procedure will be studied, such as: the admission requirements, the types of class actions and the decision that receives such demands, in order to obtain some comparative benefit from such analysis, for the objectives desired in this work, linked to the greater effectiveness of the collective process, the need to modify the current individualistic paradigm and the possibility of collectivizing individual demands.

\section{The Admissibility Requirements for Class Actions (Prerequisites)}

Rule 23 (a) (1 to 4), establishes some requirements for a demand to be received as a class action, without which the demand can only proceed individually, for the benefit of only the proposer [10].

Such requirements aim at preventing the unnecessary or harmful use of class actions, which would prejudice its genuine purposes or the collectivity affected by the decisions to be taken, and may be defined by the following expressions: Numerosity, commonality, typicality and adequacy of representation.

Numerosity is nothing more than a requirement for class actions not to be used in the hypothesis of few parties involved, that is, unnecessarily, since, in such situations it is preferred to allow individual participation in the demands [11].

Neither the law nor the precedents establish an exact number for the claim to be admitted as a collective, varying according to the circumstances of the concrete case [12]. In some situations, precedents authorize the use of class actions with eighteen or more parts and, in others, precedents indicate class actions for cases with 35 or more parts and the characteristics of the cases are important for the decision.

In the Brazilian legislation there is no norm fixing the minimum number of members of the class for the use of a class action, and there are only rules defining the hypotheses of diffuse, collective or homogeneous individual rights, to which must replace the concrete cases in order for class action to be visualized as possible, however, it seems healthy that the jurisprudence establishes some disciplines that refuse collective action when there are few parts, because of their unnecessary.

The commonality is linked with the identity of factual or juridical issues, which make the parties shares the same interests, allowing the collective judgment for all represented [13].

In cases governed by Rule 23 (b) (3), the commonality of questions must be added to the predominance of common questions over the individual ones and the superiority of the class actions over the individual mechanisms, which, according to letters (b) 3 (A) (B) (C) (D) of the alien standard will be examined taking into account the following aspects of the concrete case: a) the interest of class members in controlling demand or defense in separate process; b) the extent and nature of each dispute in relation to the dispute already brought by or against the class; c) the advantages and disadvantages of focusing the whole process on a single forum; e d) the likely difficulties in handling the class action.

This analysis usually imposes obstacles to the use of class actions in cases of mass torts, that is, mass damages [14], as for example, involving harm to health caused by the use or exposure to a harmful product.

In such cases, the particularities of each victim greatly influence the characterization of the causal link and the fixing of the value of damages, which can make the collective form inappropriate for the resolution of the dispute, especially if we consider that, by Rule 23 , the indemnities will be fixed in the collective sentence, for all classes or subclasses that the judge can create, doesn't need of the individual claims of liquidation, like it is in Brazil. On the other hand, the community of questions will also be difficult to verify in demands where members of the class represented are dispersed in different States, disciplined by different legislations [15].

In Brazil, the analysis of the commonality of questions is confused with the own analysis of collective rights hypotheses, so that, having some diffuse interest, collective stricto sensu or individual homogeneous right, there will be the presence of the commonality of interests, being important also the predominance of common issues, at least for respectable portion of the doctrine [16], but all without excess.

The typicality is related to the individual legitimacy authorized in the American system, where each individual is legitimated to propose a collective claim and to represent the replaced ones, as long as it belongs to the defended class, that is, as long as it is related to the facts narrated and intends for itself also the expected effects with the origin of the requests [17], what external a great difference in relation to the homeland where individual legitimacy is only mentioned expressly in the cases of popular actions, despite the criticisms deserved by such restriction [18].

However, the typicality has relation with the adequacy of representation, since the American legislator has assumed that the representative will only act with all possible diligence, when his interest it is also in play.

The reason followed by US legislation is necessary and appropriate, not creating any obstacle to access to justice, but rather greater security in the use of class actions, which is a great concern for North Americans, since class actions may affect individual rights that have not been excluded by means 
of the opt-out, whereby only in actions certified under Rule 23 (b) (3) [19] individuals belonging to the class may choose not to be individually affected by the collective decision, neither to benefit nor to be disadvantaged; in other cases, the whole class will be affected with no possibility of selfexclusion [20].

If it is accepted or provided the individual legitimated for collective actions in Brazil, what was desired in the preliminary draft of Collective Procedural Code, It will be also necessary to meet the typicality [21], since it is an important mechanism to try to ensure the adequacy of representation.

Finally, the adequacy of representation is a prerequisite much more related to the predicates of the lawyers who will act in the process, than to the characteristics of the substituting party, as seen in precedent previous cited by the north American author Donelan, who analyzes this issue highlighting the following adjectives for its characterization: competence, experience and other conditions to conduct a collective lawsuit [22].

Competence goes so far as to say that it must be presumed in favour of every enable lawyer, but the experience, of course, will depend on past performances, and their economic capacity will depend of the lawyers having the resources to bear all the procedural costs, until a setlement or a favourable judgment, when they will be compensated for expenses and work; in cases involving civil Rights, for example, where there may be no monetary result, the defeated defendant may be forced to pay the fees and other expenses [23].

In Brazil, the adequacy of representation was also foreseen in the preliminary draft of Collective Procedural Code in the meantime, we are afraid that a standard with such content would be manipulated to meet reprehensible ends, to prevent access to justice, especially because the lack of resources to provide for procedural expenses could never influence the admissibility of an action in the constitutional and legal perspective established in our system, where the gratuity of justice is an institute established on the constitutional and infraconstitutional levels.

Making a relationship between the prerequisites, the Brazilian theoretical and practical situation and the issue investigated in this work, comparing the collective process and the technique of collectivization of individual demands in the Brazilian and US systems, it seems necessary to conclude that before proceeding to collectivization of an individual claim, the competent judge should necessarily identify if some form of collective right is present, as it should occur when examining an initial petition of a collective action, and should decide on the class numerosity, justifying the collective crisis solution model, in addition to the typicality and adequacy of representation; the commonality of interests is confused with the analysis of the species of collective right lato sensu.

Typicality will important by confusing itself with the necessary analysis of ordinary legitimacy, supposing that the individual is accepted as author, and it relation with the adequacy of representation, that should align more to an analysis of the good faith of the parties, rather than their ability to do a good job, having in view of the democratic social model of access to justice typical of our constitutional model, which equals access for the rich and poor, assuming the competence and the good faith of all until proven otherwise.

\section{The Generic Hypotheses in Which Class Actions Are Allowed (Types of Class Actions)}

Unlike what happens in Brazil, in the United States the hypotheses of collective demands have a prediction much more focused to practical situations in which class actions would be necessary or useful, than legal concepts by means are defined of which the types of rights to be protected.

Instead of the American legislator working with concepts such as diffuse, collective or homogeneous individual rights, differentiating each one by its nature and by the link that will unite the collectivity among itself and with the opposite party, he established abstract situations in which the use of class actions would be necessary for a question of isonomy, to avoid conflicts between judicial decisions or to indemnify damages caused to the collectivity, that is, at the heart of class actions hypotheses are the ideas of: equality, coherence and integral compensation for damages.

The doctrine usually divides the types of class actions into two large groups: the first, consisting of Rule 23 (b) (2) and Rule 23 (b) (1) (A), is used in cases where injunctions or declaratory measures are required, with the aim of achieving institutional reforms, changes in social policies or the protection of civil rights; the second, consisting of Rule 23 (b) (3) or Rule 23 (b) (1) (b), is used primarily for the purpose of obtaining financial compensation, basically linked to claims for damages [24].

Thus, a class action hypothesis provided for by Rule 23 (b) (2), is when the defendant refuses to proceed in the same way with the different parties with whom he has some kind of legal relationship, which justifies the use of injunctions requiring the defendant to act isonomically with the substitutes.

By this rule it is that class actions relating to social rights, such as that which assured to black students the end of racial segregation in schools, were certified, since in this case, the cause of asking was precisely the refusal of the education system of Topeka city, Kansas State, to accept a black child, under the claim that blacks were "separate but equal" [25].

In the other case of class actions, provided for in Rule 23 (b) (1) (A), there are cases in which collective redress is aimed at preventing conflicts between judicial decisions concerning individuals belonging to the class, that would establish incompatible conduct to be observed by the opposing party, causing the US author Pace assure that such types of actions also bring benefit to the defendant.

The standard in focus has a tune very similar to the 
previous norm, so much so, the doctrine sustain the similarity between them, saying that many demands could be certified by both [26].

To illustrate cases certified by the standard in question, one can cite the demand by which professional football players claimed changes in the rules of the league.

In this sense, Pace affirm that the above two norms would be linked to the protection of indivisible rights, reason by which, as stated in the last topics, information is not required from all affected and the option of opt out is not granted.

The two standards referred to above are widely used for the protection of civil rights and the achievement of social changes, and institutional reforms in State segments linked to functions that are pathologically performed, meriting judicial intervention to conform to the law and the Constitution, and the focus of the reform of Rule 23 in 1966 was precisely to improve the protection of such rights [27].

Finally, Rule 23 (b) (3) provides for the use of class actions in the hypothesis that the questions of fact or right concerning the class predominate over the individual questions, constituting collective demand as a more efficient means of resolving the respective conflict, which in Brazil corresponds to collective action to protect individual rights that have a common origin, that is, the homogeneous individual rights.

In this case, as seen latest, the rule provides that the admissibility of a class action for damages is subordinate to the presence of two more requirements, which are: predominance of common questions over individual ones, and superiority, which is the superiority of the collective way over the individual, that is, the collective action has to present itself as a more viable means than the individual for the resolution of aggregated conflicts [28].

These rules in various situations restrict the use of collective redress in the cases of mass Torts, being questionable to us this obstacle, which may be more reasonable in the USA, where, as seen, collective sentences set the values of the compensation as a whole, being impractical the setting of individual values, which is why, many times, only the individual route can cover the particularities of the indemnifying actions mainly based to the characteristics of the victims.

Nevertheless, it should be recorded that the wave of restriction to collective actions in these cases is variable, and it can be said that it was intense in the seventies, relieved in the eighties, but revived ambivalently in the present times [29], also standing out, that in many cases the social commotion existing influence the decision and creates a precedent that expand the admission of collective actions for damages, including creating civil liability theories that reduce the burden of proof for victims or transfer it to the defendant [30].

Collective actions certified by the standard in focus, usually claim financial compensation for damages, however, collective actions aiming at financial compensation can also be certified under Rule 23 (b) (1) (B) which, however, is much less used in practice, since its wording focuses on hypotheses where there is not sufficient resources to postpone all damages, hypothesis that, in most cases is overlooked by bankruptcy claims [31].

Finally, it is interesting to remember the existence of the hybrid actions, which involve both the search for declaratory or injunctive measures, as well as compensation claims, sometimes having in the same case, subclasses seeking the scope of equity measures to staunch unequal treatments or risk of divergences, and others aimed at repairing damage [32].

For the conversion of an individual claim into a collective one, our judge should consider the type of collective right lato sensu that is the object of the demand, that is, if it is a pseudo-individual action, converted into a collective right because it relates to a diffuse or collective right stricto sensu, or if it is an action dealing with an individual right with a common origin to that of other individual rights, that is, a homogeneous individual right, worthy of being collectivized to avoid thousands of repetitive demands that would probably arise.

Similar to the US system, such identification is fundamental, given the differences in procedures linked to each category of law, if indivisible or divisible, especially with regard to the extent of the res judicata.

\section{The Decision Certifying the Action as a Class Action (Certification Order)}

In the decision by means of which a class action is certified, in addition to all the above mentioned aspects, concerning the requirements of numerosity, community, typicality, adequacy of representation, predominance of common questions and superiority of collective redress in cases involving compensation, obviously that the Court should also examine in which type of collective action the concrete case fits.

If the Court finds that this is a class actions for damages, there must be notification of each possible interested party to exercise the right to opt out if it does not wish to be covered by the judgment, communication that, for some authors, should occur in all cases, if not to allow self-exclusion, at least to allow some type of participation and follow-up [33].

The decision on certification should take place as soon as possible, in the beginning of the procedure or after the realization of a pre-certification discovery, often necessary to verification the presence of the above requirements in concrete terms, when the doctrine narrates the occurrence of an anticipation of knowledge of some issues of merit, which in some cases turns out to be useful later [34].

In addition, the decision certifying an action as class action may be changed or amended at any time prior to the final judgment if the Court is subsequently convinced by the presence, absence or loss of previously identified requirements [35].

If there is no certification, the party may proceed with its individual claim, as well as appeal to the higher court by an interlocutory appeal, applicable after legislative changes that have had this scope [36]. 
Although the decision on certification is not a final decision on the case, it may represent an insuperable barrier, in cases where there is no financial interest in individual pursuit, since many of these actions involve amounts that, if analyzed individually, are minimal [37].

Obviously, the prior contradictory is fundamental for a decision to be certified and, in most cases, after certification the defendant performs or at least proposes to perform a setlement, that is, an agreement, in order to avoid a double loss, which are a final condemnation allied to the very high costs of conducting a class action, reality that, it is said in passing, stimulated the prosecution of irresponsible actions.

Certified a claim as class action, it will be up to the Court to define the class, its claims, questions or defenses, which is fundamental to the possible exercise of the right to appeal of the decision, and appoint the class council, which, composed by lawyers of the class representatives, will be responsible by the adequacy of representation of the absent parties, reason why the Court should consider: a) the work previously carried out in identifying or investigating the rights claimed, b) the experience in collective demands, in complex cases or in cases of similar rights, c) the knowledge of the law to be applied, e d) the resources to conduct collective demand.

In Brazil, for the admission of a class action It will be up to the judge, mainly, examine whether the concrete case fits in the lato sensu collective rights hypotheses provided in the $\mathrm{CDC}$, beyond the question of legitimacy that, although provided by law, does not exempt the judge from the analysis of adequacy of representation [38].

In this sense, the STJ has been recognizing the need to satisfy the legitimacy and adequacy of representation, drawing inspiration from the US model, as extracted from the Resp 1213614 / RJ, why too general associations have been considered illegitimate, with no thematic pertinence being verified in these cases [39], which deserves a critical analysis in another opportunity, since it could restrict access to justice in a legal order and in a social context other than the US.

Tracing a relationship with the objectives pursued in this study, it should be recorded that in the decision converting an individual action into a collective action or admitting a collective claim, it is fundamental that the judge also, when justifying its action, define the class relative to the right displayed, the claim sought by the class and the reasons of that claim (which will depend on the identification of the type of collective right object of the action), in addition to the other requirements that have already been mentioned above, such as: legitimacy (typicality), the type of collective right (commonality) and the necessity of collectivization by the Number of the class (numerosity).

The duty of judicial explanation now discussed has the multiple function of allowing the courts a better office in specific cases, to society more transparency and sense of legitimacy [40] and to the parties the substantial right to participate and interfere in the procedural, principally by appealing against the decision.

\section{Conclusion}

As can be seen from the analysis presented, the American experience with class actions can contribute to the Brazilian practice linked to collective procedure and collectivization of individual demands, both when disciplining the prerequisites for the admission of a collective claim, and when define the hypotheses that could be subject to collective demands (types of class action) or the points that could be faced by the decision certifying a collective claim (Certification order).

Made this general assertion, some specific conclusions will be delimited, to demonstrate in more detail the contributions mentioned:

1. As for the requirements required by US legislation for the admission of a class action, which are: numerosity, commonality, typicality and adequacy of representation, in addition to the predominance of common issues and the superiority of collective redress over individual way in the cases of class actions for damages, it can be said that the Brazilian collective procedure would develop, if in the decisions were observed aspects related to numerosity and the commonality, which in our opinion mixed up with the identification of the species of collective right lato sensu is subject of the demand, fundamental point for the conscious conduct of the procedure and its consequences.

2. Moreover, it was observed that the typicality is important in a system that legitimizes the individual to propose of collective claims, which relates to ordinary legitimacy - since it is analyze whether the individual participates in any material legal relationship with the contrary party, and the quality of the party's actions, translated into the requirement of adequacy of representation, that in Brazil should not involve financial aspects, but only the idea of good faith, there should be no excesses in this area, so that unwanted obstacles to access to justice are not created.

3. In the field of types of class action, it has been seen that unlike the Brazilian normative body, the American rule delimit the types of class actions considering hypothetical situations where the collective conflict resolution model is necessary or useful, does not concern with the abstract definition of collective rights species, being able to contribute to Brazilian practice by existing experience on issues of admissibility of collective claims, especially in cases involving homogeneous individual rights arising from mass damages (mass Torts), where there is significant concern about access to justice for victims of harm.

4. Finally, in terms of justification of collectivization or admission of collective claim, it was seen that the experience with class actions can contribute to the Brazilian collective procedural experience when it teaches that the certification order must indicate the type of collective right in litigation, the class or group of persons to be reached, their claim and reasoning, so that the procedure develops properly, with the 
substantial participation of the parties, essential to the legitimation of the result, and naturally, to the fundamental right of access to justice.

\section{References}

[1] GAGNO, Luciano. Efetividade do processo e técnica de coletivização de demandas individuais. Curitiba: Brazil Publishing, 2019, p. 31-33.

[2] GRINOVER, Ada Pellegrini; MULLENIX, Linda; WATANABE, Kazuo. Os processos coletivos nos países de civil law e common law: uma análise de direito comparado. São Paulo: Revista dos Tribunais, 2008, p. 262-264.

[3] GIDI, Antonio. "The class action code. A model for civil law countries". Comparative Law Review, vol. 15, p. 247-267, 2013, p. 250.

[4] EUA. Rule 23 - Federal Rule of Civil Procedure (FRCP). Available in: www.law.cornell.edu/rules/frcp/rule_23. Consulted on: 20 of april of 2018.

[5] EUA. "History of Brown V. Board of Education." Available in: http://www.uscourts.gov/educational-resources/getinvolved/federal-court-activities/brown-board-education-reenactment/history.aspx. Consulted on: 20 of april of 2018.

[6] PACE, Nicholas M. "Class Actions in the United States of America: an overview of the process and the empirical literature". Available in: http://globalclassactions.stanford.edu/sites/default/files/docum ents/USA_National_Report.pdf, p. 1-99. Consulted on: 20 of april of 2018, p. 09.

[7] PACE, Nicholas M. "Class Actions in the United States of America: an overview of the process and the empirical literature. Available

in: http://globalclassactions.stanford.edu/sites/default/files/docum ents/USA_National_Report.pdf, p. 1-99. Consulted on: 20 of april of 2018, p. 14.

[8] ALEXANDER, Janet Cooper. "An introduction to Class Actions Procedure in the United States". Available in: $\mathrm{http}: / /$ law.duke.edu/grouplit/papers/classactionalexander.pdf, p. 1-25. Consulted on: 20 of april of 2018, p. 20.

[9] PACE, Nicholas M. "Class Actions in the United States of America: an overview of the process and the empirical literature. Available in: http://globalclassactions.stanford.edu/sites/default/files/docum ents/USA_National_Report.pdf, p. 1-99. Consulted on: 20 of april of $2 \overline{018}$, p. 02.

[10] FLORES, Charles R. "Appealing Class Action Certification Decisions Under Federal Rule Of Civil Procedure 23 (F)," Setton Hall Circuit Review: Vol. 4: Iss. 1, Article 2. Available in: http://erepository.law.shu.edu/circuit_review/vol4/iss1/2. Consulted on: 20 of april of 2018, p. 04.

[11] DONELAN, Charles. "Prerequisites to a Class Action Under New Rule 23." 10 B. C. L. Rev. 527 (1969), Available in: http://lawdigitalcommons.bc.edu/bclr/vol10/iss3/6. Consulted on: 20 of april of 2018 , p. 529-530.

[12] DONELAN, Charles. "Prerequisites to a Class Action Under New Rule 23.” 10 B. C. L. Rev. 527 (1969), Available in: http://lawdigitalcommons.bc.edu/bclr/vol10/iss $3 / 6$. Consulted on: 20 of april of 2018 , p. 531.

[13] DONELAN, Charles. "Prerequisites to a Class Action Under New Rule 23.” 10 B. C. L. Rev. 527 (1969), Available in: http://lawdigitalcommons.bc.edu/bclr/vol10/iss $3 / 6$. Consulted on: 20 of april of 2018, p. 532.

[14] ALEXANDER, Janet Cooper. "An introduction to Class Actions Procedure in the United States". Available in: $\mathrm{http}: / /$ law.duke.edu/grouplit/papers/classactionalexander.pdf, p. 1-25. Consulted on: 20 of april of 2018, 04-05.

[15] PACE, Nicholas M. "Class Actions in the United States of America: an overview of the process and the empirical literature". Available in: http://globalclassactions.stanford.edu/sites/default/files/docum ents/USA_National_Report.pdf, p. 1-99. Consulted on: 20 of april of 2018, p. 12.

[16] GAGNO, Luciano P. "Direito individual homogêneo: em busca de uma interpretação mais coerente com o direito fundamental de acesso à justiça". Available in: http://www.publicadireito.com.br/conpedi/manaus/arquivos/an ais/brasilia/12_619.pdf. Consulted on: 20 of april of 2018, p. 252.

[17] DONELAN, Charles. "Prerequisites to a Class Action Under New Rule 23.” 10 B. C. L. Rev. 527 (1969), Available in: http://lawdigitalcommons.bc.edu/bclr/vol10/iss3/6. Consulted on: 20 of april of 2018, p. 534.

[18] HOMBURGER, Adolf. "State class actions and the federal rule". Columbia Law Review, vol. 71, n. 4 (april., 1971), p. 609-659. Available in: http://www.jstor.org/stable/1121248. Consulted on: 20 of april of 2018 , p. 610.

[19] ALEXANDER, Janet Cooper. "An introduction to Class Actions Procedure in the United States". Available in: $\mathrm{http}: / /$ law.duke.edu/grouplit/papers/classactionalexander.pdf, p. 1-25. Consulted on: 20 of april of 2018, p. 08-09.

[20] PACE, Nicholas M. "Class Actions in the United States of America: an overview of the process and the empirical literature. Available in: http://globalclassactions.stanford.edu/sites/default/files/docum ents/USA_National_Report.pdf, p. 1-99. Consulted on: 20 of april of 2018, p. 10.

[21] BRASIL. Anteprojeto de Código Brasileiro de Processos Coletivos. In: GRINOVER, Ada Pellegrini; MENDES, Aluisio Gonçalves de Castro; WATANABE, Kazuo (Coord.). Direito processual coletivo e o anteprojeto de Código Brasileiro de Processo Coletivos, São Paulo: Revista dos Tribunais, 2007.

[22] DONELAN, Charles. "Prerequisites to a Class Action Under New Rule 23.” 10 B. C. L. Rev. 527 (1969), Available in: http://lawdigitalcommons.bc.edu/bclr/vol10/iss3/6. Consulted on: 20 of april of 2018, p. 535.

[23] ALEXANDER, Janet Cooper. "An introduction to Class Actions Procedure in the United States". Available in: http://law.duke.edu/grouplit/papers/classactionalexander.pdf, p. 1-25. Consulted on: 20 of april of 2018, p. 10-11.

[24] PACE, Nicholas M. "Class Actions in the United States of America: an overview of the process and the empirical literature. Available in: http://globalclassactions.stanford.edu/sites/default/files/docum ents/USA_National_Report.pdf, p. 1-99. Consulted on: 20 of april of 2018, p. 07. 
[25] EUA. "Brown v. Board of Education." Available in: https://supreme.justia.com/us/347/483/case.html. Consulted on: 20 of april of 2018 .

[26] PACE, Nicholas M. "Class Actions in the United States of America: an overview of the process and the empirical literature. Available

in: http://globalclassactions.stanford.edu/sites/default/files/docum ents/USA_National_Report.pdf, p. 1-99. Consulted on: 20 of april of 2018, p. $09-10$.

[27] LIND, JoEllen. "'Procedural Swift': Complex Litigation Reform, State Tort Law, and Democratic Values". Available in: http://www.classactionlitigation.com/library/lind37.4.pdf, p. 717-788. Consulted on: 20 of april of 2018, p. 758 .

[28] ALEXANDER, Janet Cooper. "An introduction to Class Actions Procedure in the United States". Available in: $\mathrm{http} / / /$ law.duke.edu/grouplit/papers/classactionalexander.pdf, p. 1-25. Consulted on: 20 of april of 2018, p. 05.

[29] LIND, JoEllen. "'Procedural Swift': Complex Litigation Reform, State Tort Law, and Democratic Values". Available in: http://www.classactionlitigation.com/library/lind37.4.pdf, p. 717-788. Consulted on: 20 of april of 2018, p. 757.

[30] ALEXANDER, Janet Cooper. "An introduction to Class Actions Procedure in the United States". Available in: http://law.duke.edu/grouplit/papers/classactionalexander.pdf, p. 1-25. Consulted on: 20 of april of 2018, p. 22.

[31] PACE, Nicholas M. "Class Actions in the United States of America: an overview of the process and the empirical literature. Available

in: http://globalclassactions.stanford.edu/sites/default/files/docum ents/USA_National_Report.pdf, p. 1-99. Consulted on: 20 of april of 2018 , p. 11 and 15.

[32] PACE, Nicholas M. "Class Actions in the United States of America: an overview of the process and the empirical literature. Available

in: http://globalclassactions.stanford.edu/sites/default/files/docum ents/USA_National_Report.pdf, p. 1-99. Consulted on: 20 of april of 2018, p. $24-\overline{25}$.
[33] ALEXANDER, Janet Cooper. "An introduction to Class Actions Procedure in the United States". Available in: http://law.duke.edu/grouplit/papers/classactionalexander.pdf, p. 1-25. Consulted on: 20 of april of 2018, p. 08.

[34] ASHLEY, Marc D. "The scope and timing of discovery in antitrust class action litigation." The Antitrust Practitioner. Volume 5, December 2006, p. 15.

[35] GRAY, Joshua B.; SEAGULL, Michelle H. "Class Action Reaction: Amended Rule 23 Enhances Judicial Supervision in Class Litigation.” Antitrust, volume 18, n. 2, p. 91-96, Spring 2004, p. 93

[36] WEIL, Jeffrey G.; KINT, Brian. "Rule 23 (f) Class Certification Appeals: Boon or Bust?" The Legal Intelligencer. ALM Media Properties, LLC. Available in: http://www.law.com/jsp/pa/PubArticleFriendlyPA.jsp?id=120 2548299218, p. 01-04. Consulted on: 20 of april of 2018, p. 01 .

[37] WEIL, Jeffrey G.; KINT, Brian. "Rule 23 (f) Class Certification Appeals: Boon or Bust?" The Legal Intelligencer. ALM Media Properties, LLC. Available in: http://www.law.com/jsp/pa/PubArticleFriendlyPA.jsp?id=120 2548299218, p. 01-04. Consulted on: 20 of april of 2018, p. 02 .

[38] COSTA, Susana Henriques da. In: (Coord.) Comentários à Lei de Ação Civil Pública e Lei de Ação Popular, São Paulo: Quartier Latin, 2006, p. 390-391.

[39] BRASIL. Superior Tribunal de Justiça. REsp 1213614 / RJ. RECURSO ESPECIAL 2010/0169344-0. Relator (a) Ministro LUIS FELIPE SALOMÃO (1140). Órgão Julgador T4 QUARTA TURMA. Data do Julgamento: 01/10/2015. Data da Publicação/Fonte DJe: 26/10/2015, RMDCPC vol. 69 p. 95.

[40] TARUFFO, Michele. "Il significato costituzionalemndell'obbligo di motivazzione". In: DINAMARCO, Candido Rangel; GRINOVER, Ada Pellegrini; WATANABE, Kazuo. Paticipação e processo. São Paulo: Revista dos Tribunais, p. 37-50, 1988, p. 38. 